PIWULANG: Jurnal Pendidikan Agama Islam, Vol. 3 No. 21 Maret 2021, 123-142

P-ISSN : 2622-5638. E-ISSN : 2622-5654

Homepage: http://e-journal.staima-alhikam.ac.id/index.php/piwulang

\title{
PENDIDIKAN BERWAWASAN MULTIKULTURAL DI LEMBAGA PENDIDIKAN ISLAM: KONSEPSI DAN IMPLEMENTASINYA DI MI NEGERI PAJU PONOROGO
}

\author{
Ahmad Wahyudi \\ STAI Ma'arif Kendal Ngawi \\ Email: Jayayudi91@gmail.com
}

\begin{abstract}
This research focuses on the study of madrasah efforts in instilling multicultural values in students as knowledge and experience that must be possessed. This research uses qualitative research methods with data collection techniques performed using in-depth interviews, participatory observation, and documentation study. Research findings related to the multicultural education model in madrasah institutions show that: first in building multicultural education is a paradigmatic view of multicultural education. Both curricula offer multicultural values to be implemented. The three madrasah cultures were developed to respect the various processes of learning inside and outside the classroom. the implications of multicultural education in the madrasa environment which shows the values of multiculturalism such as: harmony, togetherness, and brotherhood
\end{abstract}

\begin{abstract}
Abstrak
Penelitian ini memfokuskan kajian kepada upaya madrasah dalam menanamkan nilainilai multikultural kepada peserta didik sebagai pengetahuan dan pengalaman yang harus dimiliki. Penelitian ini menggunakan metode penelitian kualitatif dengan teknik pengambilan data yang dilakukan menggunakan teknik wawancara mendalam, observasi partisipasi, dan studi dokumentasi. Temuan penelitian berkaitan dengan model pendidikan multikultural di lembaga madrasah menunjukkan bahwa: pertama dalam membangun pendidikan multikultural ialah adanya pandangan paradigmatik atas pendidikan multikultural. Kedua kurikulum yang menawarkan nilai-nilai multikultural untuk diimplementasikan. Ketiga budaya madrasah yang dikembangkan untuk menghargai ragam proses dalam pembelajaran di dalam dan luar kelas. implikasi dari pendidikan multikultural di lingkungan madrasah yang menunjukkan nilai-nilai multikulturalisme seperti: kerukunan, kebersamaan, dan persaudaraan.
\end{abstract}

Kata Kunci: Pendidikan Islam, Madrasah, Multikulturalisme 
PIWULANG: Jurnal Pendidikan Agama Islam, Vol. 3 No. 21 Maret 2021, 123-142

P-ISSN : 2622-5638. E-ISSN : 2622-5654

Homepage: http://e-journal.staima-alhikam.ac.id/index.php/piwulang

\section{A. Pendahuluan}

Keberagaman merupakan aspek yang tidak dapat dipisahkan dari bangsa Indonesia yang dikenal sebagai bangsa majemuk. Kemajemukan tersebut terepresentasikan dari keberagaman bahasa, suku, adat, pemikiran, struktur demografis, dan bahkan agama. ${ }^{1}$ Pada gilirannya, salah satu problem besar bangsa Indonesia sebagai bangsa yang majemuk adalah persoalan mensikapi keberagaman tersebut. Kemajemukan yang dimiliki bangsa Indonesia sebagaimana disebutkan seharusnya menjadi sebuah potensi besar yang mampu melejitkan bangsa Indonesia ke puncak peradaban yang tinggi. Sebaliknya, kemajemukan tersebut jika tidak disikapi secara bijaksana dan dikelola secara optimal, maka ia akan berubah menjadi "bom waktu" yang setiap saat dapat memporak-porandakan bangsa besar ini dalam bingkai konflik atas nama perbedaan.

Kemajemukan masyarakat Indonesia dapat memunculkan beragam efek, baik efek positif-konstruktif maupun negatif-dekonstruktif dan diantara efek negatif yang dapat timbul darinya ialah munculnya konflikkonflik antar anak bangsa yang mengatasnamakan perbedaan. Sehubungan dengan itu, kiranya dapat disebutkan beberapa contoh konflik yang telah terjadi di Indonesia yang mengatasnamakan perbedaan baik suku, ras, maupun agama seperti di Maumere (NTT) tahun 1995, Surabaya, Situbondo, Tasikmalaya tahun 1996, Rengasdengklok tahun 1997, Jakarta dan Solo, Kupang (NTT) tahun 1998, Ambon dan Sambas tahun 1999. ${ }^{2}$ Bahkan hingga kini, konflik masih terus mewarnai dinamika kehidupan di Indonesia seperti yang terjadi antara suku Dani dan suku Moni di Papua semenjak tahun 2014, dan yang terjadi di Tanjung Balai tahun $2016{ }^{3}$

Fakta di atas menuntut adanya upaya konkret guna menanggulangi problematika keberagaman yang dapat terjadi kembali di masa yang akan datang. Salah satu upaya konkret tersebut ialah melalui serangkaian

\footnotetext{
${ }^{1}$ Berdasarkan pemaparan MPR RI bahwa Indonesia memiliki 1.128 suku bangsa (data BPS) dan bahasa, ragam agama, dan budaya di sekitar 17.508 pulau. LIhat MPR dan Tim Kerja Sosialisasi MPR RI Periode 2009-2014, Materi Sosialisasi Empat Pilar MPR RI (Jakarta: Sekjend MPR RI, 2016), hlm 1

${ }^{2}$ H. Sudarto, Konflik Islam Kristen: Menguak Akar Masalah Hubungan antar Umat Beragama di Indonesia (Semarang: Pustaka Rizki Putra, 1999), hlm xi

${ }^{3} \mathrm{http}: / /$ liputan6.com/news/read/2571163/tersangka-kasus-kerusuhan-tanjungbalaibertambah-jadi-21-orang
} 
PIWULANG: Jurnal Pendidikan Agama Islam, Vol. 3 No. 21 Maret 2021, 123-142

P-ISSN : 2622-5638. E-ISSN : 2622-5654

Homepage: http://e-journal.staima-alhikam.ac.id/index.php/piwulang

program-program pendidikan. Ngainun Naim menuturkan bahwa jika melihat realitas semacam itu -disintegrasi di tengah keberagaman- maka, konsep pluralisme dan multikulturalisme merupakan sebuah alternatif yang dapat dikembangkan untuk menyelesaikan atau paling tidak meminimalisir terjadinya konflik yang berkelanjutan. Dan salah satu media yang efektif untuk internalisasinya adalah melalui institusi pendidikan. ${ }^{4}$

Pendidikan merupakan wilayah strategis untuk menginternalisasikan nilai multikulturalisme bagi bangsa Indonesia yang majemuk dan hal tersebut mendapat respon yang positif dari banyak pihak diantaranya ialah lembaga Negara baik eksekutif maupun legislatif. Hal ini terbukti dengan diundangkannya Undang-undang Republik Indonesia No. 20 Tahun 2003 tentang Sistem Pendidikan Nasional yang mengakomodasi nilai-nilai hak asasi manusia dan semangat multikultural dan bahkan nilainilai tersebut dijadikan sebagai salah satu prinsip penyelenggaraan pendidikan nasional, sebagaimana yang termaktub pada Bab III Pasal 4, ayat $1 . .^{5}$

Melihat fakta bahwa umat Islam merupakan kelompok mayoritas (majority society) dan nilai strategis dunia pendidikan dalam mengembangkan wacana multikulturalisme, maka pendidikan Islam sebagai salah satu format pendidikan di Indonesia tentulah memiliki andil besar dalam upaya menjaga integrasi sosial di lingkungan masyarakat melalui program-program pendidikan berwawasan multikultural. Umat Islam idealnya harus menjadi pioneer bagi terwujudnya integrasi sosial masyarakat Indonesia secara keseluruhan melalui jalur pendidikan yang diwujudkan melalui serangkaian proses-proses pendidikan.

Berdasarkan landasan pemikiran akan pentingnya sikap menerima dan menghargai perbedaan (multikulturalisme), strategisnya jalur pendidikan dalam menginternalisasikan nilai-nilai multikultural, serta posisi umat Islam sebagai kelompok agama mayoritas di Indonesia, maka penelitian ini berupaya melakukan kajian yang komprehensif dengan

\footnotetext{
${ }^{4}$ Ngainun Naim, Teologi Kerukunan: Mencari Titik Temu dalam Keragaman (Jogyakarta: Teras, 2011), hlm 35-36

5 Dirjen Pendidikan Islam Departemen Agama Republik Indonesia, Undang-undang dan Peraturan Pemerintah Republik Indonesia tentang Pendidikan (Jakarta: Dirjen Pendis, 2006), hlm 9
} 
PIWULANG: Jurnal Pendidikan Agama Islam, Vol. 3 No. 21 Maret 2021, 123-142

P-ISSN : 2622-5638. E-ISSN : 2622-5654

Homepage: http://e-journal.staima-alhikam.ac.id/index.php/piwulang

menggunakan metode penelitian kualitatif dan data-data yang berasal dari lapangan penelitian atas proses pendidikan berwawasan multikultural di lembaga pendidikan Islam (madrasah) agar nantinya hasil studi ini dapat dijadikan refleksi dan bahan referensi lebih lanjut mengenai proses pendidikan berwawasan multikultural di madrasah.

\section{B. Metode Penelitian}

Penelitian ini menggunakan metodologi penelitian kualitatif yang memiliki karakteristik alami (natural setting) sebagai sumber data langsung, bersifat deskriptif, dan proses lebih penting dibandingkan hasil. ${ }^{6}$ Adapun rancangan penelitian yang dipakai dalam penelitian ini adalah studi kasus. Kehadiran peneliti dalam penelitian kualitatif menjadi suatu hal yang mutlak. Dengan adanya peneliti di lokasi penelitian, maka segala informasi yang ingin diketahui mudah untuk dicari. Ciri khas penelitian kualitatif tidak dapat dipisahkan dari pengamatan berperan serta, sebab peranan penelitilah yang menentukan keseluruhan skenarionya. ${ }^{7}$ Untuk itu, dalam penelitian ini, peneliti bertindak sebagai instrumen kunci, dan pengumpul data, sedangkan instrumen yang lain sebagai penunjang.

Lokasi penelitian ini ialah lembaga pendidikan Islam di jenjang pendidikan dasar yakni MIN Paju Ponorogo. Adapun pemilihan lokasi dilakukan secara purposive (bertujuan), dengan beberapa alasan diantaranya: Pertama, lembaga tersebut merepresentasikan gambaran masyarakat multikultural yang beragam. Kedua, Berdasarkan kajian awal peneliti, kebijakan pendidikan di lembaga tersebut merepresentasikan nilai penghargaan terhadap keberagaman yang muncul di kedua lembaga mulai dari kepemimpinan dan budaya sekolah yang sensitif gender yang ditunjukkan oleh kepala madrasah yang dijabat oleh seorang perempuan, bimbingan intensif untuk siswa yang dianggap lamban mengikuti materi pembelajaran agar mampu mengejar ketertinggalannya dari yang lain, penghargaan untuk setiap prestasi peserta didik, budaya demokrasi, dan lain sebagainya.

Adapun Sumber data dalam penelitian ini ialah: a).Person (orang) yaitu sumber, melalui wawancara, atau tindakan melalui pengamatan di

\footnotetext{
${ }^{6}$ Lexy Moleong, Metodologi Penelitian Kualitatif(Bandung: Remaja Rosdakarya, 2000), hlm 117

${ }^{7}$ Ibid., 135
} 
PIWULANG: Jurnal Pendidikan Agama Islam, Vol. 3 No. 21 Maret 2021, 123-142

P-ISSN : 2622-5638. E-ISSN : 2622-5654

Homepage: http://e-journal.staima-alhikam.ac.id/index.php/piwulang

MIN Paju Ponorogo. Dalam penelitian ini sumber datanya adalah kepala madrasah, guru, dan peserta didik di Madrasah tersebut. b). Place (tempat) yaitu sumber data yang menyajikan lampiran berupa keadaan diam dan bergerak. Sumber data tempat meliputi gedung sekolah, kelas, alam sekitar, perpustakaan dan lain sebagainya. Dan c). Paper atau dokumen-dokumen yang berkaitan dengan keadaan di MIN Paju Ponorogo dan tema yang sedang dikaji dalam penelitian ini.

Dalam penelitian ini, peneliti melakukan pengumpulan data dengan teknik: 1). Observasi Partisipasi. Sugiyono mengemukakan bahwa observasi merupakan suatu proses yang kompleks, suatu proses yang tersusun dari berbagai proses biologis dan psikologis. Dua di antara yang terpenting adalah proses-proses pengamatan dan ingatan. 8 Teknik pengumpulan data dengan observasi digunakan bila penelitian berkenaan dengan perilaku manusia, proses kerja, gejala-gejala alam, dan bila responden yang diamati tidak terlalu besar. 2). Wawancara Mendalam (Indept Interview). Wawancara adalah percakapan dengan maksud tertentu oleh dua pihak, yaitu pewawancara (interviewer) sebagai pengaju/pemberi pertanyaan dan yang diwawancarai (interviewee) sebagai pemberi jawaban atas pertanyaan itu. 9 Dalam penelitian ini peneliti menggunakan wawancara mendalam dengan teknik wawancara tak berstruktur. Dan 3). Studi Dokumentasi. Dokumentasi yang diambil dalam penelitian berupa dokumen tentang pelaksanaan pendidikan berbasis multikultural baik dokumen pembelajaran maupun di luar pembelajaran serta implikasinya dalam membentuk perilaku sosial siswa di lingkungan madrasah.

Analisis data dalam penelitian kualitatif dilakukan sejak sebelum memasuki lapangan, selama di lapangan, dan setelah selesai di lapangan. Teknik analisis data dalam kasus ini menggunakan analisis data kualitatif, 10 mengikuti konsep yang diberikan Miles dan Huberman. Miles dan Huberman, mengemukakan bahwa aktivitas dalam analisis data kualitatif dilakukan secara interaktif dan berlangsung secara terus menerus pada setiap tahapan penelitian, sehingga sampai tuntas dan datanya sampai

8 Sugiyono, Metodologi Penelitian Pendidikan: Pendekatan Kuantitatif, Kualitatif, dan R\&D (Bandung: Alfabeta, 2006), hlm 203-205

${ }_{9}^{9}$ Basrowi dan Suwandi, Memahami Penelitian Kualitatif (Jakarta: Rineka Cipta, 2008), hlm 127 10 Mattew B Miles dan A. Michael Huberman, Analisis Data Kualitatif, Terj Tjetjep Rohendi Rohidi (Jakarta: UI Press, 1992) hlm 16 
PIWULANG: Jurnal Pendidikan Agama Islam, Vol. 3 No. 21 Maret 2021, 123-142

P-ISSN : 2622-5638. E-ISSN : 2622-5654

Homepage: http://e-journal.staima-alhikam.ac.id/index.php/piwulang

jenuh. Adapun tahapan analisis data dalam penelitian ini ialah Pengumpulan Data, Reduksi Data, Display Data, dan Pengambilan Kesimpulan.

\section{Temuan Penelitian}

Undang-undang Nomor 20 Tahun 2003 tentang Sistem Pendidikan Nasional menyebutkan bahwa Pendidikan adalah usaha sadar dan terencana untuk mewujudkan suasana belajar dan proses pembelajaran agar peserta didik secara aktif mengembangkan potensi dirinya untuk memiliki kekuatan spiritual keagamaan, pengendalian diri, kepribadian, kecerdasan, akhlak mulia, serta keterampilan yang diperlukan dirinya, masyarakat, bangsa dan Negara. ${ }^{11}$ Dalam definisi ini, pendidikan di Indonesia diarahkan pada pembentukan manusia paripurna yakni mereka yang memiliki kecerdasan, keterampilan, dan karakter mulia sebagai warga negara Indonesia.

Konteks bangsa Indonesia yang plural menuntut adanya upaya dari berbagai elemen masyarakat untuk turut berperan serta dalam menanamkan sikap yang menjunjung tinggi multikulturalisme sebagai bagian dari jati diri bangsa Indonesia. Lembaga pendidikan sebagai mitra masyarakat sekaligus bagian dari birokrasi pemerintah jelas memiliki peran sentral dalam upaya internalisasi nilai-nilai multikulturalisme dengan mewujudkannya ke dalam program-program pendidikan di sekolah/madrasah.

Temuan penelitian yang didapatkan di MIN Paju Ponorogo terkait pendidikan berwawasan multikultural terwujud dalam tiga komponen yakni: Pertama, kebijakan pendidikan berwawasan multikultural yang ditunjukkan lembaga madrasah dengan ditemukannya corak pikir pengelola pendidikan di MIN Paju Ponorogo yang mengedepankan pendidikan inklusif, terbuka, egaliter, dan tidak memihak pada suatu kelompok/golongan tertentu. ${ }^{12}$

Penuturan informan mengenai konsep pendidikan yang mengedepankan inklusifitas dan egaliterianisme di atas didukung dengan adanya dokumen penyusunan dan pengembangan kurikulum yang

\footnotetext{
${ }^{11}$ Dirjen Pendis Departemen Agama Republik Indonesia, Undang-undang..., hlm 5

12 Wawancara peneliti dengan Kepala MI Negeri Paju Ponorogo tentang visi, misi, arah, dan tujuan pengelolaan madrasah
} 
PIWULANG: Jurnal Pendidikan Agama Islam, Vol. 3 No. 21 Maret 2021, 123-142

P-ISSN : 2622-5638. E-ISSN : 2622-5654

Homepage: http://e-journal.staima-alhikam.ac.id/index.php/piwulang

merepresentasikan keterlibatan berbagai pihak dalam pengambilan keputusan kurikulum diantaranya ialah pengelola (Kepala Madrasah dan Guru), Pengawas Pendidikan, dan Komite Madrasah yang mewakili aspirasi masyarakat luas karena terdiri dari beberapa komponen masyarakat. ${ }^{13}$ Pelibatan masyarakat untuk menentukan arah laju pendidikan di madrasah tentu sangat penting dan strategis, mengingat lembaga pendidikan merupakan bagian integral dari masyarakat dan tidak boleh menjadi "menara gading" yang menjauh dari kehidupan masyarakat luas sebagai end users pendidikan. Pelibatan masyarakat ini juga sebagai bentuk otonomi pendidikan dan penghargaan terhadap keberagaman aspirasi masyarakat yang majemuk.

Temuan selanjutnya berkaitan dengan kebijakan pendidikan berwawasan multikultural di MIN Paju Ponorogo ialah tumbuh suburnya budaya madrasah yang menekankan sikap multikulturalisme seperti kerukunan, toleransi, dan saling menghargai. Berdasarkan penggalian data ditemukan bahwa MIN Paju Ponorogo terlihat begitu concern pada upaya pembentukan sikap sosial peserta didik guna memenuhi kriteria sebagai warga Negara Indonesia yang menyadari dan menghargai keberagaman yang dimiliki bangsa Indonesia ini. Hal tersebut tercermin dari apa yang disampaikan oleh Kepala MIN Paju Ponorogo bahwa nilai kekeluargaan ditekankan sebagai budaya keseharian di lingkungan madrasah. ${ }^{14}$

Menguatkan pernyataan kepala madrasah di atas, peneliti menemukan fakta bahwa dokumen kurikulum MIN Paju Ponorogo dikembangkan agar pendidikan berwawasan multikultural, yakni pendidikan yang menghargai nilai-nilai keberagaman dan sikap peduli sosial diantara peserta didik diimplementasikan di dalam kehidupan madrasah sehari-hari. Kurikulum MIN Paju Ponorogo menunjukkan bahwa terdapat tiga model pendidikan dalam membentuk sikap sosial peserta didik. Pertama, peduli sosial ditanamkan sebagai bagian dari pendidikan kecakapan hidup yang dalam istilahnya disebut sebagai General Life Skill. Kedua, Pendidikan karakter yang diantaranya ialah toleransi dan peduli sosial. Ketiga, Pendidikan ragam budaya dan karakter bangsa yang

\footnotetext{
13 Temuan dokumen penyusunan Kurikulum di MIN Paju Ponorogo yang dalam proses pengembangannya melibatkan banyak pihak di madrasah serta beragam stakeholder pendidikan lainnya termasuk aspirasi masyarakat

${ }^{14}$ Wawancara peneliti dengan Kepala MI Negeri Paju Ponorogo tentang budaya madrasah yang mengedepankan aspek kekeluargaan dan persamaan derajat
} 
PIWULANG: Jurnal Pendidikan Agama Islam, Vol. 3 No. 21 Maret 2021, 123-142

P-ISSN : 2622-5638. E-ISSN : 2622-5654

Homepage: http://e-journal.staima-alhikam.ac.id/index.php/piwulang

mencakup aspek Agama, Pancasila, Budaya, dan Tujuan Pendidikan Nasional Indonesia. ${ }^{15}$ Dari pemaparan isi kurikulum tersebut, dapat dipahami bahwa budaya kerukunan dan kebersamaan telah menjadi wacana dan kebijakan di MIN Paju Ponorogo yang kemudian diimplementasikan dalam kegiatan pendidikan di madrasah sebagai sebuah strategi penanaman nilai sosial-multikultural kepada peserta didik.

Komponen Kedua temuan penelitian di MIN Paju Ponorogo yakni berkaitan dengan implementasi pendidikan berwawasan multikultural yang dilaksanakan baik di dalam kelas maupun di luar kelas. Proses implementasi pendidikan berwawasan multikultural di dalam kelas selalu identik dengan proses pembelajaran. Dalam kaitannya dengan proses pembelajaran tersebut, hal penting yang harus dipahami adalah prinsip penting pendidikan multikultural yakni belajar hidup dalam perbedaan. Pendidikan konvensional pada umumnya hanya bersandar pada tiga pilar utama yaitu: learning how to know, learning how to do, dan learning how to be, maka dalam pendidikan multikultural, ditambah satu pilar lagi yakni: learning how to live together and work together with others. Penanaman pilar keempat sebagai suatu jalinan komplementer terhadap tiga pilar lainnya dalam praktik pendidikan meliputi:

a. Pengembangan sikap toleran, empati, dam simpati

b. Membangun sikap saling percaya

c. Memelihara saling pengertian

d. Menjunjung tinggi sikap saling menghargai. ${ }^{16}$

Implementasi pendidikan berwawasan multikultural yang dilakukan di dalam kelas di MIN Paju Ponorogo diawali dengan fakta tertanamnya kesadaran akan pentingnya sikap menghargai perbedaan yang dimiliki oleh seorang guru saat mengajar di dalam kelas. Di MIN Paju Ponorogo guru diwajibkan untuk memiliki kepekaan akan keragaman yang ada di dalam kelas yang diampunya seperti bersikap inklusif terhadap keberagaman kondisi fisik, latar belakang, karakter, kemampuan belajar, dan gaya belajar

\footnotetext{
15 Temuan dokumen penyusunan Kurikulum di MIN Paju Ponorogo yang diarahkan untuk membentuk sikap sosial peserta didik

16 Jiyanto dan Amirul Eko Efendi, Implementasi Pendidikan Multikultural di Madrasah Inklusi Madrasah Aliyah Negeri Maguwoharjo Yogyakarta (Jurnal Penelitian, Volume 10, Nomor 01, Februari 2016), hlm 34
} 
PIWULANG: Jurnal Pendidikan Agama Islam, Vol. 3 No. 21 Maret 2021, 123-142

P-ISSN : 2622-5638. E-ISSN : 2622-5654

Homepage: http://e-journal.staima-alhikam.ac.id/index.php/piwulang

peserta didik yang ada di dalam kelas yang diampunya. ${ }^{17}$ Konsepsi yang dimiliki guru sebagaimana disebutkan merupakan tonggak awal dalam pelaksanaan pendidikan multikultural yang anti-diskriminasi, saling menghargai, dan penuh empati.

Temuan penelitian berikutnya menunjukkan bahwa proses implementasi nilai-nilai multikultural yang dilakukan guru di dalam kelas dilakukan dengan melakukan pembiasaan/pembudayaan sikap yang menghargai multikulturalisme, serta pembelajaran materi yang berwawasan multikultural dengan menggunakan strategi pengelolaan dan pembelajaran yang mendukung nilai-nilai multikulturalisme. Pembiasaan dan pembudayaan sikap simpati, empati, peduli dan saling menghargai ditanamkan dengan beragam langkah-langkah positif di dalam kelas diantaranya ialah menciptakan susasana kelas yang kondusif, merotasi secara rutin posisi tempat duduk peserta didik agar mereka terbiasa berinteraksi dengan banyak rekan berbeda, dan juga bekerja dalam team yang berbeda pula seperti dituturkan oleh guru kelas MIN Paju Ponorogo. ${ }^{18}$ Keterangan yang diberikan oleh guru kelas tersebut menggambarkan bagaimana suasana kelas yang dibangun di setiap kelas di MIN Paju Ponorogo menunjukkan bahwa nilai kerukunan dan kebersamaan menjadi suasana sehari-hari di madrasah. Pernyataan tersebut kemudian dikuatkan dengan pengamatan lebih lanjut peneliti terhadap proses pembelajaran yang ada di kelas-kelas di MIN Paju Ponorogo, dimana peneliti mendapati bahwa kegiatan belajar-mengajar yang ada di kelas dilakukan dengan aktif, berbasis kerja kelompok, interaksi yang intens antar peserta didik, serta pendekatan individual dari guru untuk membantu peserta didik dalam mengatasi kesulitan belajar mereka. ${ }^{19}$

Silabus dan RPP di MIN Paju Ponorogo menunjukkan bahwa pembelajaran di MIN Paju Ponorogo memperhatikan nilai-nilai karakter peduli sosial sebagai bagian dari nilai yang akan dikembangkan di dalam kelas. ${ }^{20}$ Rencana Pembelajaran disiapkan dengan beragam strategi berbasis

\footnotetext{
17 Wawancara dengan Kepala Madrasah dan Guru Kelas V di MIN Paju Ponorogo tentang perspektif guru dan madrasah akan keragaman yang dimiliki peserta didik.

18 Wawancara dengan Guru Kelas V MIN Paju Ponorogo tentang proses pembiasaan dan pembudayaan sikap empati dan peduli diantara peserta didik di dalam kelas.

${ }_{19}$ Observasi peneliti terhadap kegiatan belajar-mengajar yang dilakukan guru di dalam kelas.

${ }^{20}$ Studi Dokumentasi terhadap Dokumen Pembelajaran (RPP) Guru di MIN Paju Ponorogo
}

- Ahmad Wahyudi - 131 
PIWULANG: Jurnal Pendidikan Agama Islam, Vol. 3 No. 21 Maret 2021, 123-142

P-ISSN : 2622-5638. E-ISSN : 2622-5654

Homepage: http://e-journal.staima-alhikam.ac.id/index.php/piwulang

cooperative learning dan active learning (pembelajaran dengan kerja sama dan keaktifan di dalam kelas). ${ }^{21}$ Selanjutnya yang menarik bagi peneliti pada temuan penelitian ini ialah para guru dalam setiap proses pembelajaran di kelas menetapkan rangkaian kegiatan pembelajaran kooperatif yang ditujukan untuk membantu siswa agar dapat bersosialisasi secara positif dalam keberagaman yang ada di dalam kelasnya. Hal ini diketahui berdasarkan crosscheck temuan data bahwa guru yang diwawancarai tentang pembelajaran kooperatif ialah guru kelas sedangkan dokumen Silabus dan RPP merupakan perencanaan pembelajaran mata pelajaran Agama (Al-Qur'an-Hadits) yang tidak diampu oleh guru kelas. Fakta ini menunjukkan bahwa konsep pembelajaran berbasis nilai-nilai multikulturalisme telah menjadi "ruh" dan acuan tetap bagi setiap guru di MIN Paju Ponorogo dalam mengajar sehari-hari di dalam kelas.

Implementasi pendidikan berwawasan multikultural yang dilakukan di luar kelas di MIN Paju Ponorogo diberikan melalui rangkaian kegiatan pendidikan di luar kelas seperti Pramuka, olahraga, kegiatan-kegiatan sosial, pembiasaan, dan melalui poster-poster yang secara tidak langsung menjadi media pengembangan nilai-nilai multikulturalisme. ${ }^{22}$ Salah satu kegiatan ekstrakurikuler yakni Pramuka menjadi langkah strategis dan telah lama menjadi media dalam pengembangan sikap sosial peserta didik. Kegiatan Pramuka di MIN Paju Ponorogo banyak mengambil setting lokasi di alam bebas atau di luar kelas serta menerapkan banyak materi yang berbasis kerja sama dan saling membantu diantara peserta didik. Hal ini tergambar jelas dari pengamatan peneliti pada kegiatan Pramuka di MIN Paju Ponorogo yang mengambil setting lokasi di luar kelas. ${ }^{23}$ Dalam kegiatan tersebut, anak banyak terlibat dalam kerja kelompok dan saling membantu antar peserta didik baik laki-laki maupun perempuan, besar ataupun kecil, berasal dari latar belakang keluarga mampu atau kurang mampu semuanya saling bekerja sama dengan baik tanpa membedakan.

Kegiatan-kegiatan lain di luar kelas lain yang juga menjadi media dalam internalisasi nilai-nilai multikultural di MIN Paju Ponorogo adalah kegiatan-kegiatan sosial seperti kegiatan Hari Kartini yang ditujukan untuk

\footnotetext{
${ }^{21}$ Studi Dokumentasi terhadap Dokumen Pembelajaran (RPP) Guru di MIN Paju Ponorogo

22 Wawancara dengan Kepala Madrasah MIN Paju Ponorogo tentang pembiasaan peduli sosial kepada peserta didik di luar pembelajaran dalam kelas

23 Observasi peneliti pada kegiatan ekstrakurikuler Pramuka di MIN Paju Ponorogo
}

- Ahmad Wahyudi - 132 
PIWULANG: Jurnal Pendidikan Agama Islam, Vol. 3 No. 21 Maret 2021, 123-142

P-ISSN : 2622-5638. E-ISSN : 2622-5654

Homepage: http://e-journal.staima-alhikam.ac.id/index.php/piwulang

menghormati emansipasi wanita, bantuan bencana alam, dan kegiatan santunan kepada peserta didik yang kurang mampu pada momen-momen tertentu untuk menanamkan rasa simpati dan empati antar peserta didik. Berdasarkan observasi peneliti, MIN Paju Ponorogo melaksanakan kegiatan santunan bagi peserta didik yang membutuhkan bersamaan dengan upacara peringatan Hari Kartini meskipun tidak selalu bersamaan dengan hari Kartini. ${ }^{24}$ Kegiatan ini merupakan rangkaian kegiatan madrasah yang selalu diagendakan dalam rangka memberikan pendidikan sosial kepada peserta didiknya agar memiliki sikap simpati dan empati terhadap beragam keadaan di sekelilingnya.

Temuan ketiga dalam penelitian ini menunjukkan adanya implikasi kegiatan-kegiatan pendidikan berwawasan multikultural di MIN Paju Ponorogo dalam mengarahkan dan membiasakan peserta didik agar memiliki nilai dan sikap yang bernilai multikultural. Dalam amatan peneliti, peserta didik MIN Paju Ponorogo dalam keseharian menunjukkan sikap yang mencerminkan nilai-nilai multikulturalisme dalam perilaku keseharian mereka sebagai hasil dari kegiatan-kegiatan pendidikan. Sikap tersebut diantaranya adalah kesediaan untuk bekerja sama dalam menyelesaikan tugas-tugas kelompok di kelas, mereka tidak lagi mempermasalahkan status gender, latar belakang, tingkat kecerdasan, tingkat kecakapan dan beragam perbedaan lainnya dalam kegiatan seharihari di kelas. Perilaku peserta didik yang mencerminkan sikap produktif terhadap nilai-nilai multikultural juga tercermin dalam pergaulan mereka sehari-hari di luar kelas. Indikatornya ialah dapat direduksinya potensipotensi konflik diantara peserta didik melalui pembiasaan dan pembudayaan sikap yang mencerminkan nilai-nilai multikultural.

Indikator lain tercermin dalam sikap keseharian peserta didik yang cenderung terbuka dan tidak memilih-milih teman serta tidak munculnya fenomena geng di lingkungan madrasah yang mana fenomena geng ini adalah bentuk lain dari sikap tribalisme dan primordialisme yang bertentangan dengan prinsip dan nilai-nilai multikultural. Fakta ini kiranya cukup menggambarkan bagaimana sikap peserta didik terbentuk sebagai

${ }^{24}$ Observasi peneliti atas kegiatan di luar kelas yang ditujukan untuk membangun sikap empati dan peduli sosial seperti: bantuan bencana alam, santunan Yatim Piatu, PHBN, dan PHBI 
PIWULANG: Jurnal Pendidikan Agama Islam, Vol. 3 No. 21 Maret 2021, 123-142

P-ISSN : 2622-5638. E-ISSN : 2622-5654

Homepage: http://e-journal.staima-alhikam.ac.id/index.php/piwulang

hasil dari penerapan konsepsi pendidikan multikultural dalam proses pendidikan di madrasah. ${ }^{25}$

\section{Diskusi Hasil Penelitian}

Temuan penelitian berkaitan dengan kebijakan pendidikan berwawasan multikultural di MIN Paju Ponorogo sebagaimana telah dipaparkan sejalan dengan konsepsi yang diajukan Aji Nugroho tentang pendidikan Islam berwawasan multikultural yakni bertujuan untuk: 1) menghapuskan "prejudice", dan sekaligus sebagai media untuk melatih dan membangun karakter siswa agar mereka mampu bersikap demokratis, humanis dan pluralis; 2) membangun pemahaman keberagaman siswa yang inklusif sehingga mampu meminimalisir jarak sosial antar peserta didik dalam menjalani perbedaan mereka; 3) mengajarkan bagaimana cara hidup di tengah keragaman yang ada di dalam bangsanya; 4) memberikan perlindungan terhadap diskriminasi; 5) mengakui dan mengakomodasi kebebasan individu kelompok minoritas, seperti berbicara, berkelompok, menjalankan agama dan sebagainya yang berakar dari nilai-nilai kebebasan, kesetaraan dan demokrasi, sehingga hak-hak kultural minoritas dapat terakomodasi dengan baik, yang berarti bahwa setiap peserta didik mempunyai hak untuk masuk dalam budaya tertentu, ikut dibentuk dan membentuk budaya itu. ${ }^{26}$

Pemikiran dan kebijakan program-program pendidikan berwawasan multikultural sebagaimana digagas dan dikembangkan oleh lembaga MIN Paju Ponorogo dalam konteks pendidikan agama oleh Kasinyo Harto dinyatakan sebagai "pandangan paradigmatik" dalam memaknai pendidikan agama berbasis multikulturalisme yang didefinisikan sebagai gerakan pembaruan dan inovasi pendidikan agama dalam rangka menanamkan kesadaran akan pentingnya hidup bersama dalam keragaman dan perbedaaan, dengan spirit kesetaraan dan kesederajatan, saling percaya, saling memahami dan menghargai persamaan, perbedaan dan

\footnotetext{
25 Observasi peneliti atas perilaku sehari-hari peserta didik di luar kelas yang menunjukkan sikap kekeluargaan, peduli sosial, dan tidak membedakan teman bahkan semenjak kelas bawah 26 Muhammad Aji Nugroho, Pendidikan Islam Berwawasan Multikultural; Sebuah Upaya Membangun Pemahaman Keberagamaan Inklusif pada Umat Muslim (Jurnal Mudarrisa, Vol 8, No. 1, Juni 2016), hlm 31
} 
PIWULANG: Jurnal Pendidikan Agama Islam, Vol. 3 No. 21 Maret 2021, 123-142

P-ISSN : 2622-5638. E-ISSN : 2622-5654

Homepage: http://e-journal.staima-alhikam.ac.id/index.php/piwulang

keunikan masing-masing. 27 Paradigma pendidikan multikultural sebagaimana dipaparkan Harto di atas merupakan nilai-nilai multikultural yang sudah selayaknya menjadi bagian dari pendidikan di Indonesia seperti kesadaran akan pentingnya hidup bersama, semangat kesetaraan, menghargai perbedaan dan terjadinya relasi yang positif diantara berbagai kelompok yang berbeda dan paradigma yang sedemikian tercermin dalam ragam kebijakan pendidikan berwawasan multikultural di MIN Paju Ponorogo.

Kebijakan yang mengakomodir nilai-nilai multikulturalisme di MIN Paju Ponorogo diarahkan untuk mereduksi atau bahkan menghilangkan prasangka, stereotip, dan prejudice karena prasangka, stereotip dan terlebih lagi diskriminasi merupakan sebuah gejala yang dapat memicu beragam konflik yang mengatasnamakan perbedaan. Prasangka negatif pada kelompok/golongan lain harus sedini mungkin direduksi dengan menanamkan nilai-nilai penerimaan dan penghargaan terhadap keberagaman yang ada di sekitar mereka. Pada wilayah pendidikan, sebagaimana dikemukakan oleh Fattah Hanurawan bahwa gejala prasangka di sekolah yang memiliki murid dari berbagai latar belakang budaya akan menghambat perkembangan kemampuan sosial siswa untuk hidup dalam komunitas multikultural. ${ }^{28}$ Dengan demikian pemikiran yang inklusif, egaliter, dan penuh empati menjadi persoalan penting yang harus ditanamkan kepada para peserta didik sejak dini. Hingga tahapan ini, MIN Paju Ponorogo telah berusaha dengan maksimal untuk mengembangkan kebijakan-kebijakan yang peduli dengan nilai-nilai multikulturalisme sebagai bentuk ikhtiar intelektual lembaga guna mengeliminir sikap-sikap yang kontra produktif terhadap keberagaman.

Kegiatan-kegiatan pendidikan berwawasan multikultural yang terdapat di MIN Paju Ponorogo menunjukkan bahwa proses implementasi pendidikan berwawasan multikultural dijalankan melalui serangkaian program pembelajaran dan pembiasaan untuk bersikap empati, inklusif, dan egaliter di dalam kelas. Proses pembelajaran di dalam kelas lalu didukung dengan kegiatan luar kelas seperti ekstrakurikuler Pramuka, Out

27 Kasinyo Harto, Pengembangan Pendidikan Agama Islam Berbasis Multikultural (Jurnal AlTahrir, Vol. 14, No. 2 Mei 2014), hlm 419

28 Fattah Hanurawan, Sikap Guru terhadap Peran Pengajaran Kajian Multikultural dalam Mengurangi Prasangka Siswa (Jurnal Ilmu Pendidikan, Jilid 4, No. 3, Agustus 1997), hlm 132 
PIWULANG: Jurnal Pendidikan Agama Islam, Vol. 3 No. 21 Maret 2021, 123-142

P-ISSN : 2622-5638. E-ISSN : 2622-5654

Homepage: http://e-journal.staima-alhikam.ac.id/index.php/piwulang

Bond, kegiatan sosial dan kegiatan penunjang lain di madrasah. Berkaitan dengan proses tersebut, Studi Rahman Wahid menunjukkan bahwa praksis pendidikan multikultural harus dijalankan dengan melandaskan pada kebijakan untuk saling menghargai dan toleransi dalam tata tertib dan pembiasaan kultur sekolah. Selain itu program sekolah juga menunjang implementasi pendidikan multikultural seperti ekstrakulikuler serta program-program tahunan lain (pentas seni, studi budaya, dan gelar kreatifitas). Dalam proses pembelajaran integrasi konten multikultural dilakukan dalam mata pelajaran PKn dengan menggunakan metode pembelajaran demonstrasi dan bermain peran. ${ }^{29}$

Al Arifin lebih lanjut memberikan penegasan dan pemetaan tentang praksis pendidikan multikultural bahwa praktik pendidikan multikultural di Indonesia dapat dilaksanakan secara fleksibel, tidak harus dalam bentuk mata pelajaran yang terpisah atau monolitik. Pelaksanaan pendidikan multikultural didasarkan atas lima dimensi yakni: (1) integrasi konten, (2) proses penyusunan pengetahuan, (3) mengurangi prasangka, (4) pedagogi setara, serta (5) budaya sekolah dan struktur sekolah yang memberdayakan. ${ }^{30}$

Proses pendidikan berwawasan multikultural di MIN Paju Ponorogo sebagaimana yang telah dipaparkan secara keseluruhan telah menunjukkan bentuk-bentuk pengimplementasian nilai-nilai multikulturalisme sebagaimana konsepsi pendidikan multikultural yang dikonsepsikan oleh James Banks. Secara umum, Banks menyatakan bahwa yang dimaksud pendidikan multikultural ialah:

"Multicultural education is an idea, an educational reform movement, and a process whose major goal is to change the structure of educational institutions so that male and female students, exceptional students, and

\footnotetext{
${ }^{29}$ Rahman Wahid, Implementasi Pendidikan Multikultural di Pendidikan Dasar (Skripsi: Tidak diterbitkan, 2020)

30 Ahmad Hidayatullah Al Arifin, Implementasi Pendidikan Multikultural dalam Praksis Pendidikan di Indonesia (Jurnal Pembangunan Pendidikan: Fondasi dan Aplikasi Vol. 01, No. 01, Juni 2012), hlm 77-78
} 
PIWULANG: Jurnal Pendidikan Agama Islam, Vol. 3 No. 21 Maret 2021, 123-142

P-ISSN : 2622-5638. E-ISSN : 2622-5654

Homepage: http://e-journal.staima-alhikam.ac.id/index.php/piwulang

students who are members of diverse racial, ethnic, and cultural groups will have an equal chance to achieve academically in school". 31

James Banks dalam uraiannya tersebut secara komprehensif telah menyebutkan tiga komponen sekaligus yang berkaitan dengan implementasi pendidikan multikultural yakni konsepsi tentang pendidikan multikultural, proses pelaksanaan pendidikan multikultural, sekaligus hasil yang diharapkan dengan diberlakukannya pendidikan multikultural di lembaga pendidikan sebagaimana penjelasan berikut:

1. An Idea (ide/konsepsi)

Ide atau konsep ini mewakili kesadaran bahwa semua siswa memiliki karakteristik khusus karena usia, agama, gender, kelas sosial, etnis, ras, atau karakteristik budaya tertentu yang melekat pada diri masing-masing. Pendidikan Multikultural berkaitan dengan ide bahwa semua siswa tanpa memandang karakteristik budayanya itu seharusnya memiliki kesempatan yang sama untuk belajar di sekolah. Perbedaan yang ada itu merupakan keniscayaan atau kepastian adanya namun perbedaan itu harus diterima secara wajar dan bukan untuk membedakan. Artinya perbedaan itu perlu kita terima sebagai suatu kewajaran dan perlu sikap toleransi agar kita bisa hidup berdampingan secara damai tanpa melihat unsur yang berbeda itu untuk membeda-bedakan. ${ }^{32}$

Kesadaran akan urgensi nilai multikultural di MIN Paju Ponorogo -dan seharusnya juga di lembaga yang lain- merupakan unsur pertama dan utama dalam membentuk konsepsi pendidikan multikultural yang menghargai keberagaman peserta didik. Kesadaran ini yang kemudian diwujudkan ke dalam konsep regulasi berupa kurikulum dan perencanaan pembelajaran serta budaya madrasah berwawawasan multikultural yang dikembangkan di MIN Paju Ponorogo.

2. Education Reform Movement (Gerakan Pembaharuan Pendidikan)

\footnotetext{
31 James Banks (ed), Encyclopedia of Diversity in Education (California: Sage Publishing, 2012), hlm 2248

32 Sutarno, Pendidikan Multikultural: Unit 1 (Jakarta: Direktorat Jenderal Pendidikan Tinggi Departemen Pendidikan Nasional, 2007), hlm 21-22
} 
PIWULANG: Jurnal Pendidikan Agama Islam, Vol. 3 No. 21 Maret 2021, 123-142

P-ISSN : 2622-5638. E-ISSN : 2622-5654

Homepage: http://e-journal.staima-alhikam.ac.id/index.php/piwulang

Pendidikan Multikultural bisa muncul berbentuk bidang studi, program, dan praktik yang direncanakan lembaga pendidikan untuk merespon tuntutan, kebutuhan dan aspirasi berbagai kelompok. Pendidikan berwawasan multikultural bukan sekedar merupakan praktik aktual satu bidang studi atau program pendidikan semata, namun mencakup seluruh aspek pendidikan. ${ }^{33}$

Gerakan pembaruan pendidikan berwawasan multikultural diwujudkan dengan upaya yang dilakukan oleh madrasah untuk mengajarkan dan menanamkan nilai-nilai multikulturalisme kepada peserta didik baik dalam konteks pembelajaran maupun di luar pembelajaran sebagaimana yang terjadi MIN Paju Ponorogo. Namun, yang perlu digarisbawahi bahwa pendidikan multikultural merupakan proses (pendidikan) yang tujuannya tidak akan pernah terealisasikan secara penuh. ${ }^{34}$

Pendidikan Multikultural adalah proses menjadi. Pendidikan multikultural harus dipandang sebagai suatu proses yang terusmenerus (an ongoing process), dan bukan sebagai sesuatu yang langsung bisa tercapai sehingga pendidikan multikultural harus senantiasa diajarkan kepada peserta didik melalui beragam dimensi pendidikan di madrasah.

3. Major Goals (Tujuan Utama Pendidikan Multikultural)

Tujuan pendidikan multikultural yang dimaksud James Banks ialah adanya kesetaraan kesempatan (an equal chance) bagi peserta didik yang beragam. Peserta didik baik laki-laki maupun perempuan, berkebutuhan khusus, dan berasal dari beragam latar belakang seluruhnya berhak untuk mendapatkan pendidikan yang sama.

Fakta di MIN Paju Ponorogo menunjukkan sikap dan perilaku peserta didik telah menunjukkan apa yang disebut oleh James Banks sebagai an equal chance (kesempatan yang sama). Peserta didik di lembaga tersebut dapat saling bekerja sama untuk mencapai satu tujuan yang sama. Sikap yang ditunjukkan oleh para peserta didik menunjukkan nilai kerukunan yang menjadi cita-cita dari pendidikan multikultural. Tidak munculnya kelompok-kelompok kecil (geng) di

${ }^{33}$ Sutarno, Pendidikan Multikultural... Hlm. 21-22

${ }^{34}$ Sutarno, Pendidikan Multikultural... Hlm. 21-22

- $\quad$ Ahmad Wahyudi - 138 
PIWULANG: Jurnal Pendidikan Agama Islam, Vol. 3 No. 21 Maret 2021, 123-142

P-ISSN : 2622-5638. E-ISSN : 2622-5654

Homepage: http://e-journal.staima-alhikam.ac.id/index.php/piwulang

lingkungan madrasah menunjukkan tidak adanya sikap yang menunjukkan primordialisme dan tribalisme yang kontra produktif dengan nilai-nilai pendidikan multikultural.

Uraian di atas menunjukkan bahwa proses pendidikan berwawasan multikultural di MIN Paju Ponorogo menunjukkan singkronisasinya dengan konsepsi-konsepsi yang diberikan oleh para ahli dan peneliti lain yang menyatakan bahwa proses pendidikan multikultural haruslah memiliki landasan yang kokoh berupa tujuan yang ingin dicapai beserta kebijakan-kebijakan yang mengakomodir nilai-nilai multikulturalisme, dalam implementasinya pendidikan multikultural tidak harus berbentuk mata pelajaran tersendiri namun lebih mengutamakan proses pendidikan multikultural yang mengejawantah dalam kegiatan sehari-hari peserta didik baik di dalam kelas maupun di luar kelas.

Sebagai penutup, akan penulis tunjukkan beberapa variabel nilai-nilai multikultural yang berusaha ditanamkan di MIN Paju Ponorogo berdasarkan temuan-temuan penelitian yang dapat digunakan sebagai bahan refleksi bagi implementasi pendidikan multikultural di masa dan waktu yang berbeda, diantara variabelvariabel tersebut adalah:

a. Kerja sama. Kerja sama merupakan bagian tak terpisahkan dari nilai multikulturalisme yang ingin dikembangkan di MIN Paju Ponorogo mengingat tujuan dari pendidikan multikultural adalah agar peserta didik dapat saling bekerja sama satu sama lain secara positif. Proses ini ditunjukkan oleh madrasah mulai dari proses pengembangan kurikulum hingga proses pembelajaran.

b. Toleransi. Toleransi di MIN Paju Ponorogo dikembangkan dengan menumbuhkan sikap simpati, empati, dan peduli dengan sesama. Adapun caranya banyak ditempuh dengan kegiatan-kegiatan pembelajaran yang menumbuhkan interaksi yang intensif diantara peserta didik. Strategi lain juga ditempuh dengan kegiatan-kegiatan sosial seperti santunan anak yatim, bantuan bencana alam, dan lain sebagainya.

c. Kesederajatan. Hubungan kekeluargaan yang erat antara gurupeserta didik dan sesama peserta didik merupakan upaya 
PIWULANG: Jurnal Pendidikan Agama Islam, Vol. 3 No. 21 Maret 2021, 123-142

P-ISSN : 2622-5638. E-ISSN : 2622-5654

Homepage: http://e-journal.staima-alhikam.ac.id/index.php/piwulang

madrasah untuk membangun sikap kesederajatan diantara mereka. Fokus dari nilai ini ialah menghilangkan kesenjangan diantara sesama warga madrasah.

d. Persaudaraan. Puncak dari pendidikan berwawasan multikultural ialah perilaku peserta didik yang mau menerima dan menghargai perbedaan yang muncul di sekitar mereka secara positif. Adapun cara yang ditempuh di MIN Paju Ponorogo ialah membangun iklim kekeluargaan dan suasana persaudaraan diantara peserta didik dan juga pendidik. Nilai persaudaraan inilah yang sejatinya harus diajarkan dan dibiasakan kepada seluruh peserta didik di Indonesia sebagai penduduk negeri yang majemuk seperti Indonesia.

\section{E. Kesimpulan}

Kebijakan Pendidikan berwawasan multikultural di MI Negeri Paju Ponorogo disimpulkan menjadi tiga faktor diantaranya: a) Paradigma madrasah dan juga pendidik terhadap nilai-nilai multikultural menjadi penggerak utama dan pertama dalam implementasi pendidikan multikultural di madrasah. b) Pemberlakuan regulasi, kode etik, kurikulum, dan rencana pembelajaran di madrasah merupakan tahap lanjut dari gagasan tentang pendidikan multikultural. c) Budaya madrasah yang bersifat sosial-multikultural penting untuk dikembangkan dalam rangka memberikan pengajaran secara tidak langsung mengenai arti penting pendidikan berwawasan multikultural. Implementasinya melalui: 1). Implementasi Pendidikan Multikultural di Dalam Kelas. Proses Internalisasi pendidikan multikultural di dalam kelas di MI Negeri Paju Ponorogo terwujud dalam proses pembelajaran yang menekankan aspek kerja sama, saling bertukar pendapat dengan menekankan pada proses pembelajaran berbasis cooperative learning. Dan 2). Implementasi Berwawasan Multikultural di Luar Kelas berbasis kelompok yang dapat menumbuhkan kerja sama dan saling membantu tanpa pandang bulu.

Interaksi sosial peserta didik di madrasah terjalin dengan baik. Indikatornya ialah dapat diminimalisirnya konflik, pertengkaran, ataupun permusuhan yang terjadi diantara peserta didik, dapat direduksinya fenomena negatif yang bersifat tribalistik seperti geng, serta sikap sosial 
PIWULANG: Jurnal Pendidikan Agama Islam, Vol. 3 No. 21 Maret 2021, 123-142

P-ISSN : 2622-5638. E-ISSN : 2622-5654

Homepage: http://e-journal.staima-alhikam.ac.id/index.php/piwulang

peserta didik yang menunjukkan kesediaan untuk hidup bersama dan bekerja sama.

\section{Daftar Pustaka}

Aji Nugroho, Muhammad. Pendidikan Islam Berwawasan Multikultural; Sebuah Upaya Membangun Pemahaman Keberagamaan Inklusif pada Umat Muslim. Jurnal Mudarrisa, Vol 8, No. 1, Juni 2016

Banks, James (ed). Encyclopedia of Diversity in Education. California: Sage Publishing, 2012

Basrowi dan Suwandi. Memahami Penelitian Kualitatif. Jakarta: Rineka Cipta, 2008

Dirjen Pendidikan Islam Departemen Agama Republik Indonesia. Undang-undang dan Peraturan Pemerintah Republik Indonesia tentang Pendidikan. Jakarta: Dirjen Pendis, 2006

Hanurawan, Fattah. Sikap Guru terhadap Peran Pengajaran Kajian Multikultural dalam Mengurangi Prasangka Siswa. Jurnal Ilmu Pendidikan, Jilid 4, No. 3, Agustus 1997

Harto, Kasinyo. Pengembangan Pendidikan Agama Islam Berbasis Multikultural. Jurnal Al-Tahrir, Vol. 14, No. 2 Mei 2014

Hidayatullah Al Arifin, Ahmad. Implementasi Pendidikan Multikultural dalam Praksis Pendidikan di Indonesia. Jurnal Pembangunan Pendidikan: Fondasi dan Aplikasi Vol. 01, No. 01, Juni 2012

http://liputan6.com/news/read/2571163/tersangka-kasus-kerusuhan-tanjungbalai-

bertambah-jadi-21-orang

Jiyanto dan Eko Efendi, Amirul. Implementasi Pendidikan Multikultural di Madrasah Inklusi Madrasah Aliyah Negeri Maguwoharjo Yogyakarta. Jurnal Penelitian, Volume 10, Nomor 01, Februari 2016

Miles, B Mattew dan Huberman, A Michael. Analisis Data Kualitatif, Terj Tjetjep Rohendi Rohidi. Jakarta: UI Press, 1992

Moleong, Lexy. Metodologi Penelitian Kualitatif. Bandung: Remaja Rosdakarya, 2000 
PIWULANG: Jurnal Pendidikan Agama Islam, Vol. 3 No. 21 Maret 2021, 123-142

P-ISSN : 2622-5638. E-ISSN : 2622-5654 Homepage: http://e-journal.staima-alhikam.ac.id/index.php/piwulang

MPR dan Tim Kerja Sosialisasi MPR RI Periode 2009-2014. Materi Sosialisasi Empat Pilar MPR RI. Jakarta: Sekjend MPR RI, 2016

Naim, Ngainun. Teologi Kerukunan: Mencari Titik Temu dalam Keragaman. Yogyakarta: Teras, 2011

Sudarto, H. Konflik Islam Kristen: Menguak Akar Masalah Hubungan antar Umat Beragama di Indonesia. Semarang: Pustaka Rizki Putra, 1999

Sugiyono. Metodologi Penelitian Pendidikan: Pendekatan Kuantitatif, Kualitatif, dan $R \& D$. Bandung: Alfabeta, 2006

Sutarno. Pendidikan Multikultural: Unit 1. Jakarta: Direktorat Jenderal Pendidikan Tinggi Departemen Pendidikan Nasional, 2007

Wahid, Rahman. Implementasi Pendidikan Multikultural di Pendidikan Dasar. Skripsi: Tidak diterbitkan, 2020 